\title{
PENGARUH KUALITAS PRODUK, HARGA DAN CITRA MEREK TERHADAP KEPUTUSAN PEMBELIAN MOBIL TOYOTA CALYA DI NASMOCO SLAMET RIYADI SURAKARTA
}

\author{
Thoriq Amri Yahya, Burhanuddin, Rochmi Widayanti \\ Program Studi Manajemen, Universitas Islam Batik Surakarta \\ Email :ay_thoriq@yahoo.com
}

\begin{abstract}
This study was conducted to determine how much the influence of the independent variables consisting of product quality, price and brand image on the purchase decision of the Toyota Calya car in Nasmoco slamet Riyadi Surakarta. The sample in this study was 78 respondents taken from the consumer population who bought a Toyota Calya car at Nasmoco Slamet Riyadi in the period 2017-2018. The technique used is purposive sampling. As in general quantitative research, this research uses $t$-test analysis techniques for hypothesis testing, $F$ test and multiple linear regression analysis. The results of the $f$ test produce Fcalculate $=35,644$ indicating that the variable of product quality, price and brand image jointly influence the purchasing decision of the Toyota Calya car at Nasmoco Slamet Riyadi. The results of the t test show the most dominant price variable influencing the dependent variable $(Y)$ with a value of $t$ calculate $=2.688$
\end{abstract}

Keywords : product quality, price, brand image, purchasing decisions

\section{PENDAHULUAN}

Beberapa tahun terakhir industri otomotif nasional semakin ramai dengan meluncurkan produk produk baru ke pasaran. Menurut gaikindo (gabungan industri otomotif Indonesia) pasar otomotif nasional masih dikuasai toyota dengan pangsa pasar 35,3\% hingga kuartal III tahun 2017. Perkembangan pesat dialami produk mobil tipe LCGC (Low Cost Green Car) Toyota yang terdiri dari tipe Agya dan Calya. Penjualan mobil LCGC Toyota meningkat $17 \%$ dibanding tahun sebelumnya dalam periode yang sama. Segmentasi toyota Calya yang menyasar konsumen dengan tingkat ekonomi menengah ke bawah membuat banyaknya peminat karena harga yang relatif murah dibandingkan dengan mobil pada umumnya. Jumlah penjualan Calya itu sendiri menempati urutan teratas dibandingkan dengan 2 produk dari merek lain, yaitu daihatsu sigra dan Datsun Go panca dengan market share 31,9\%.

Dominasi toyota Calya juga terjadi di tingkat regional seperti di area solo raya dimana total market share mencapai $58,2 \%$. Keberhasilan Toyota dalam merebut pasar kendaraan LCGC dilatarbelakangi oleh beberapa aspek, salah satunya karena citra merek yang dimiliki sudah dikenal oleh masyarakat luas. Dalam penelitian Amron (2018) menyebutkan bahwa peran brand image begitu penting karena ketika informasi terhadap produk tidak dikuasai oleh konsumen, maka langkah yang diambil konsumen tersebut adalah menggunakan brand image dalam memilih produk yang akan dibeli. Keputusan pembelian mobil juga dipengaruhi oleh variasi produk, harga dan promosi (Ma'ruf, 2017). Rukmini (2016) menemukan bahwa bauran pemasaran juga mempengaruhi seseorang dalam memutuskan pembelian. Lebih lanjut Amron 
(2018) menyebutkan selain brand image terdapat variabel lain yang mempengaruhi konsumen melakukan pembelian produk otomotif, yaitu kualitas produk dan harga.

Menurut Priyambodo (2013) dalam penelitiannya menyebutkan pada umumnya kualitas produk itu disepadankan dengan ukuran relatif kebaikan dari produk baik barang ataupun jasa. Sedangkan harga yaitu kelengkapan yang melekat pada suatu barang yang memungkinan barang tersebut dapat memenuhi keinginan, kebutuhan dan memuaskan konsumen (satisfaction) yang dinyatakan dengan uang.

Menurut Sudaryono (2016) bahwa keputusan pembelian dirumuskan sebagai proses konsumen telahmelakukan pemilihan produk terbaik menurut persepsinya diantara alternatif- alternatif pilihan yang ada, selanjutnya alternatif pilihan tersebut diperoleh dengan pengumpulan informasi yang jumlah dan tingkat kepentingannya tergantung kebutuhan serta situasi yang dihadapi konsumen tersebut. Setelah melihat beberapa fakta yang melatarbelakangi seperti yang telah disebutkan di atas maka dapat diajukan sebuah penelitian dengan judul : "Pengaruh Kualitas Produk, Harga dan Citra Merek Dalam Keputusan Pembelian Mobil Toyota Calya di Nasmoco Slamet Riyadi Surakarta".

\section{KAJIAN TEORI}

a. Konsep pemasaran

Pemasaran mampu mengubah kebutuhan manusia akan sesuatu menjadi sebuah keinginan. Sebagian manusia tidak hanya ingin memenuhi kebutuhan dasarnya tersebut bahkan sebagian yang lain ingin memenuhi keinginannya pula. Proses dalam pemenuhan kebutuhan dan keinginan manusia tersebut merupakan sebuah konsep yang disebut sebagai konsep pemasaran.

b. Kualitas produk

Kotler dan Armstrong mengemukakan bahwa kualitas produk berkaitan dengan nilai dan kepuasan pelanggan karena kinerja produk tersebut bergantung pada kualitas produk itu sendiri, sebagaimana kualitas jasa yang baik akan meningkatkan kepuasan pelanggan.

Terdapat 7 indikator kualitas produk antara lain kinerja, kesesuaian dengan spesifikasi, daya tahan, keandalan, fitur-fitur, estetika dan kesan kualitas yang melekat pada produk (Tjiptono, 2008).

c. Harga

Menurut Amrullah (2016) harga merupakan sejumlah nominal yang harus dibayarkan oleh konsumen unt uk memperoleh produk tertentu. Pada umumnya indikator dari harga dibagi menjadi 5 item yaitu: keterjangkauan harga, kesesuaian harga dengan kualitas produk, daya saing harga, kesesuaian harga dengan manfaat, serta harga mempengaruhi daya beli konsumen (Kotler dan Armstrong, 2008). 
d. Citra merek

Menurut Utami (2016) brand image yaitu anggapan yang dimiliki pelanggan terhadap suatu merek yang

digambarkan melalui asosiasi merek yang ada dalam ingatan pelanggan, sedangkan asosiasi pelanggan itu sendiri merupakan segala sesuatu yang berhubungan dengan ingatan kepada merek tertentu. Menurut Tjiptono (2005) terdapat 3 indikator Citra merek yaitu : citra pembuat, citra pemakai dan citra produk.

e. Perilaku konsumen

Menurut Swasta (2010:9) perilaku konsumen merupakan tindakan-tindakan yang dilakukan oleh individu yang terlibat secara langsung di dalam proses pengambilan keputusan pada persiapan dan penentuan kegiatan-kegiatan tersebut.

f. Keputusan pembelian

Keputusan pembelian merupakan proses dalam pembelian yang nyata, apakah membeli atau tidak.

Proses keputusan pembelian :

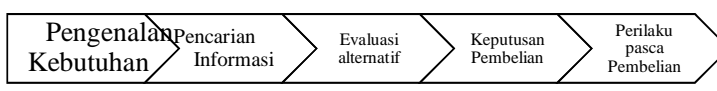

Sumber : Kotler dan Keller (2012:179)

Kerangka pemikiran

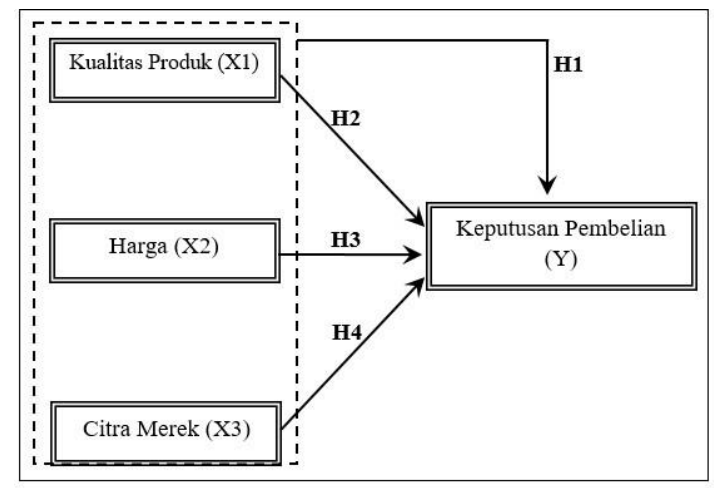

\section{METODE PENELITIAN}

Penelitian merupakan penelitian kausal dengan pendekatan kuantitatif yang bertujuan untuk mengetahui pengaruh variabel tertentu. Sampel dalam penelitian ini yaitu para pemilik mobil Toyota Calya yang melakukan pembelian di Nasmoco Slamet Riyadi. Teknik pngambilan sampel dengan purposive sampling. Jumlah sampel ditentukan dengan perhitungan slovin. 


\section{HASIL PENELITIAN DAN PEMBAHASAN}

a. Uji instrumen

1) Uji validitas

Pengujian validitas menggunakan Pearson-correlation langkahnya adalah menghitung relasi nilai yang diperoleh dari item-item pertanyaan dari variable yang terdiri dari kualitas produk, harga, citra merek dan keputusan pembelian.

Hasil Uji Validitas:

\begin{tabular}{|c|c|c|c|c|}
\hline Variabel & Item & $\mathrm{I}_{\text {hitung }}$ & $\mathrm{r}_{\text {rabel }}$ & Keterangan \\
\hline Kualitas Produk & $\mathrm{X} 1.1$ & 0,582 & 0,220 & Valid \\
& $\mathrm{X} 1.2$ & 0,556 & 0,220 & Valid \\
& $\mathrm{X} 1.3$ & 0,745 & 0,220 & Valid \\
& $\mathrm{X} 1.4$ & 0,843 & 0,220 & Valid \\
& $\mathrm{X} 1.5$ & 0,685 & 0,220 & Valid \\
& $\mathrm{X} 1.6$ & 0,670 & 0,220 & Valid \\
& $\mathrm{X} 1.7$ & 0,736 & 0,220 & Valid \\
& $\mathrm{X} 1.8$ & 0,800 & 0,220 & Valid \\
& $\mathrm{X} 1.9$ & 0,628 & 0,220 & Valid \\
\hline Variabel & $\mathrm{X} 1.10$ & 0,722 & 0,220 & Valid \\
\hline Harga & $\mathrm{Item}$ & $\mathrm{I}_{\text {hintug }}$ & $\mathrm{I}_{\text {tabel }}$ & Keterangan \\
\hline & $\mathrm{X} 2.1$ & 0,646 & 0,220 & Valid \\
& $\mathrm{X} 2.3$ & 0,663 & 0,220 & Valid \\
& $\mathrm{X} 2.4$ & 0,678 & 0,220 & Valid \\
& $\mathrm{X} 2.5$ & 0,740 & 0,220 & Valid \\
& $\mathrm{X} 2.6$ & 0,804 & 0,220 & Valid \\
& $\mathrm{X} 2.7$ & 0,813 & 0,220 & Valid \\
& $\mathrm{X} 2.8$ & 0,765 & 0,220 & Valid \\
\hline
\end{tabular}

\begin{tabular}{|c|c|c|c|c|}
\hline Citra Merek & X3.1 & 0,493 & 0,220 & Valid \\
& X3.2 & 0,661 & 0,220 & Valid \\
& X3.3 & 0,658 & 0,220 & Valid \\
& X3.4 & 0,713 & 0,220 & Valid \\
& X3.5 & 0,777 & 0,220 & Valid \\
& X3.6 & 0,577 & 0,220 & Valid \\
\hline Keputusan & Y.1 & 0,652 & 0,220 & Valid \\
Pembelian & Y.2 & 0,708 & 0,220 & Valid \\
& Y.3 & 0,557 & 0,220 & Valid \\
& Y.4 & 0,570 & 0,220 & Valid \\
& Y.5 & 0,571 & 0,220 & Valid \\
& Y.6 & 0,641 & 0,220 & Valid \\
& Y.7 & 0,665 & 0,220 & Valid \\
& Y.8 & 0,661 & 0,220 & Valid \\
& Y.9 & 0,648 & 0,220 & Valid \\
& Y.10 & 0,626 & 0,220 & Valid \\
\hline
\end{tabular}

2) Uji reliabilitas

Uji reliabilitas dalam penelitian ini dilakukan dengan menghitung cronbach's alpha dari tiap instrument dalam satu variabel, dengan kriteria standar nilai cronbach's alpha adalah 0,60 .

\begin{tabular}{|l|c|c|c|}
\hline \multicolumn{1}{|c|}{ Variabel } & $\begin{array}{c}\text { Koefisien } \\
\text { Alpha }\end{array}$ & Kriteria & Keterangan \\
\hline Kualitas & 0,882 & $>0,60$ & Reliabel \\
Produk $\left(\mathrm{X}_{1}\right)$ & & & \\
Harga $\left(\mathrm{X}_{2}\right)$ & 0,853 & $>0,60$ & Reliabel \\
$\begin{array}{l}\text { Citra Merek } \\
\text { (X) }\end{array}$ & 0,721 & $>0,60$ & Reliabel \\
$\begin{array}{l}\text { Keputusan } \\
\text { Pembelian }\end{array}$ & 0,824 & $>0,60$ & Reliabel \\
$(\mathrm{Y})$ & & & \\
\hline
\end{tabular}


b. Uji asumsi klasik

1) Uji normalitas

Uji normalitas pada penelitian ini menggunakan uji Kolmogorov Smirnov dengan membandingkan antara asymp. sign. (2-tailed) dengan tingkat signifikansi $(\alpha) 5 \%$. Hasil yang diperoleh adalah sebagai berikut:

\begin{tabular}{|c|c|}
\hline & $\begin{array}{c}\text { Unstandardiz } \\
\text { ed. Residual }\end{array}$ \\
\hline $\mathrm{N}$ & 78 \\
Kolmogorov-Smirnov Z & 0,526 \\
Asymp. Sig. (2-tailed) & 0,945 \\
\hline
\end{tabular}

Nilai Kolmogorov-Smirnov Z sebesar 0,526; dengan nilai signifikan atau asymp. sig (2- tailed) 0,945 lebih besar dari 0,05 (p-value >0,05), artinya bahwa data residual dari model regresi dalam penelitian ini terdistribusi dengan normal.

2) Uji multikolinearitas

Pengujian multikolinieritas dilakukan untuk menguji apakah dalam model regresi ditemukan adanya korelasi antar variabel independen. Dapat dilihat dalam tabel:

\begin{tabular}{|l|c|r|l|}
\hline Variabel & Tolerance & VIF & Keterangan \\
\hline Kualitas Produk (X1) & 0,353 & 2,836 & Bebas Multikolinearitas \\
\hline Harga (X2) & 0,354 & 2,822 & Bebas Multikolinearitas \\
\hline Citra Merek (X3) & 0,608 & 1,644 & Bebas Multikolinearitas \\
\hline
\end{tabular}

3) Uji heteroskedastisitas

Uji heteroskedastisitas bertujuan untukiiimenguji apakah dalam sebuah model regresi terjadi ketidaksamaan variance $d$ ari residual satu pengamatan kepengamatan yang lain. Untuk mendeteksi tidak adanya heterokedastisitas digunakan model regresi grafik scatterplot dan uji statistik dengan metode Glejser Test.

c. Analisis regresi linier berganda

Regresi linier berganda digunakan untuk membuktikan hipotesis penelitian yang menyatakan terdapat pengaruh dari variabel independen yaitu, kualitas produk, harga, dan citra merek terhadap variabel dependen yaitu, keputusan pembelian. Hasil yang diperoleh adalah sebagai berikut 
Hasil Regresi Linier Berganda:

\begin{tabular}{|l|c|c|c|}
\hline \multicolumn{1}{|c|}{ Variabel } & Koefisien Regresi & $\mathrm{T}$ & Sig. \\
\hline Konstan & 7,586 & - & - \\
\hline Kualitas Produk (X1) & 0,249 & 2,365 & 0,021 \\
\hline Harga (X2) & 0,412 & 2,688 & 0,009 \\
\hline Citra Merek (X3) & 0,426 & 2,489 & 0,015 \\
\hline $\mathrm{R}=0,769$ & \\
\hline Fhitung $=35,644$ & \\
\hline $\mathrm{R}^{2}=0,591$ & \\
\hline Sig. F $=0,000$ &
\end{tabular}

Fungsi atau persamaan sebagai berikut: $\mathrm{Y}=7,586+0,249(\mathrm{X} 1)+0,412(\mathrm{X} 2)$ $+0,426(\mathrm{X} 3)+\mathrm{e}$

d. Uji Goodness of Fit

1) Koefisien Determinasi $\left(R^{2}\right)$

Koefisien determinasi digunakan untuk mengukur seberapa besar kemampuan variabel independen dalam menggambarkan variabel dependennya. Nilai koefisien determinasi adalah antara nol dan satu. Hasil koefisien determinasi $\left(\mathrm{R}^{2}\right)$ adalah sebagai berikut:

\begin{tabular}{|c|c|c|c|}
\hline R & R Square & $\begin{array}{c}\text { Adjusted R } \\
\text { Square }\end{array}$ & $\begin{array}{c}\text { Std. Error } \\
\text { of the } \\
\text { Estimate }\end{array}$ \\
\hline 0,769 & 0,591 & 0,574 & 2,852 \\
\hline
\end{tabular}

2) Uji F (simultan)

Uji statistic F digunakan untuk mengetahui pakah semua variable independen yang dimaksudkan dalam model mempunyai pengaruh secara simultan terhadap variabel dependen. Hasil uji F ditunjukkan pada tabel berikut:

Hasil Uji F

\begin{tabular}{|c|c|l|c|}
\hline $\begin{array}{c}\text { Fhitun } \\
\mathrm{g}\end{array}$ & $\begin{array}{c}\text { Fta } \\
\text { bel }\end{array}$ & Sig. & $\begin{array}{c}\text { Keteran } \\
\text { gan }\end{array}$ \\
\hline $\begin{array}{c}35,64 \\
4\end{array}$ & $\begin{array}{c}2 \hat{3} \\
4\end{array}$ & 0,000 & $\begin{array}{c}\text { Model } \\
\text { Fit }\end{array}$ \\
\hline
\end{tabular}


e. Uji hipotesis (Uji t)

Pengujian hipotesis dilakukani dengan menggunakan uji t yang digunakan untuk menguji koefisien regresi secara individual (parsial) yakni dengan melihati pengaruh antara variabel independen terhadap variable dependen. Hasil yang diperoleh adalah sebagai berikut:

Hasil Uji t

\begin{tabular}{|c|c|c|c|c|}
\hline Variabel & thitung & ttabel & Sig. & Hipotesis \\
\hline $\begin{array}{l}\text { Kualitas Produk } \\
\text { (X1) }\end{array}$ & 2,365 & 1,992 & 0,021 & Diterima \\
\hline Harga (X2) & 2,688 & 1,992 & 0,009 & Diterima \\
\hline $\begin{array}{l}\text { Citra Merek } \\
\text { (X3) }\end{array}$ & 2,489 & 1,992 & 0,015 & Diterima \\
\hline
\end{tabular}

\section{KESIMPULAN}

a. Kesimpulan

1) Secara keseluruhan variabel independen yang terdiri dari variabel kualitas produk, harga dan citra merek memiliki pengaruh positif terhadap keputusan pembelian mobil Calya di Nasmoco Slamet Riyadi.

2) Variabel kualitas produk berpengaruh positif terhadap keputusan pernbelian mobil Toyota Calya di Nasmoco Slamet Riyadi,

3) Variabel harga produk berpengaruh positif terhadap keputusan pembelian mobil Toyota Calya di Nasmoco Slamet Riyadi

4) Variabel citra merek berpengaruh positif terhadap keputusan pembelian mobil Toyota Calya di Nasmoco Slamet Riyadi.

b. Saran

1) Pihak perusahaan yang menaungi dealer penjual produk Toyota Calya hendaknya memastikan kepuasan konsumen pasca pembelian dengan tujuan meyakinkan konsumen bahwa keputusan pembeliannya sudah tepat melalui pelayanan bengkel dan penanganan komplain yang prima.

2) Persepsi konsumen terhadap kualitas produk Calya menjadi feedback bagi perusahaan agar kedepannya dilakukan perbaikan di bagian kualitas produk dengan menerapkan refreshment model untuk tujuan meningkatkan jumlah penjualan mengingat sejak di-launching tahun 2016 Toyota Calya belum ada perubahan model. 


\section{DAFTAR PUSTAKA}

Amron, Amron, (2018). Effects Of Product Quality, Price, And Brand Image On The Buying Decision Of City Car Product. Archives of Business Research - Vo1.6,NO.4. Semarang,

Buchan, Alma. (2009). Manajemen Pemasaran dan Pemasaran Jasa. Cetakan Kelima. Edisi Revisi. Bandung: Alfabeta.

Kotler, Philip., dan Garry Amstrong. (2008). Prinsip-prinsip Pemasaran. Jilid I. Jakarta: Erlangga.

Kotler, Phillip., dan Kevin Lane Keller. (2012). Marketing Management, Edisi 14. Global Edition. Pearson Prentice Hall.

Ma'ruf, M. H. (2017). The Influence Of Product Variations, Prices And Sales Promotions On Consumer Decisions In Buying Mitsubishi Cars In Surakarta. International Journal of Economics, Business and Accounting Research (IJEBAR), 1(01).

Rukmini, R., \& Kristiyanti, L. M. S. (2016). Faktor Yang Mempengaruhi Keputusan Mahasiswa Baru Menempuh Kuliah Di Stie Aas Ditinjau Dari Marketing Mix. Jurnal Akuntansi dan Pajak, 17(01).

Sudaryono. (2016). Manajemen Pemasaran Teori dan Implementasi. Yogyakarta: Andi Tjiptono, Fandy. 2008. Strategi Pemasaran. Edisi Ketiga. Yogyakarta: CV. Andi Offset.

Utami, Vera Agusta Mei. (2016). Pengaruh Kualitas Produk, Harga dan Citra Merek Terhadap Keputusan Pembeli Pembelian, Jurnal Ilmu Riset Dan Manajemen, Vol. 5, No. 7. Juli 2016. 